\title{
Life cycle assessment of edible insects for food protein: a review
}

\author{
Afton Halloran ${ }^{1}$ (I) Nanna $^{\text {Roos }}{ }^{1} \cdot$ Jørgen Eilenberg $^{2} \cdot$ Alessandro Cerutti $^{3}$. \\ Sander Bruun ${ }^{2}$
}

\begin{abstract}
Compared to their vertebrate counterparts in traditional husbandry, insects are extremely efficient at converting organic matter into animal protein and dietary energy. For this reason, insects for food and feed show great potential as an environmentally friendly choice in future food systems. However, to obtain a true assessment of this, more information is needed about the production systems. Currently, only six studies applying the life cycle assessment (LCA) method to insect production systems have been published. The studies are heterogenous and thus difficult to compare. The aim of this paper was to establish a versatile reference framework that would allow for the selection of standardized settings for LCA applications in insect production systems, taking both the peculiarity of each system and the latest developments in food LCA into account. It is recommended that future LCAs of insect production systems take the following into account: (1) clear definition of the insect species and life stages included in the LCA, (2) use of at least two of the following types of functional units: nutritional, mass, or economic-based, (3) collection of empirical data in situ (e.g., on farms/production sites), (4) comparative analysis where production systems produce products that are realistic alternatives to the insect species under investigation, (5) inclusion of additional or
\end{abstract}

Afton Halloran

aha@nexs.ku.dk; aftonhalloran@gmail.com

1 Department of Nutrition, Exercise and Sports, University of Copenhagen, Rolighedsvej 25, 1958 Frederiksberg C, Denmark

2 Department of Plant and Environmental Sciences, University of Copenhagen, Thorvaldsensvej 40, 1871 Frederiksberg C, Denmark

3 Department of Agricultural Sciences, Forestry and Food, University of Turin, Largo Braccini 2, 10095 Gugliasco, Turin, Italy previously unconsidered unit processes, such as processing and storage and waste management, and (6) use of a wide range of impact categories, especially climate change, resource consumption, nutrient enrichment potential, acidification potential, and impacts on land and water consumption in order to allow for comparison between studies.

Keywords Insect production - Life cycle assessment . Environmental impacts $\cdot$ Mini-livestock $\cdot$ Insect farming

\section{Contents}

1. Introduction

2. Considerations for modeling insect production systems

2.1. LCA studies on insect production systems: general aspects

2.2 Goal and scope
2.2.1 Recommendations - choice of functional unit

2.3 Inventory analysis

2.3.1. Construction of facilities

2.3.2 Feed

2.3.3 Production

2.3.3.1 Temperature

2.3.3.2 Energy consumption

2.3.3.3 Feed conversion ratio

2.3.3.4 Water

2.3.3.5 Greenhouse gas emissions

2.3.3.6 Additional inputs

2.3.4 Transport

2.3.5 Processing and storage

2.3.6 Waste management and nutrient recycling

2.3.7 Recommendations - modeling of the insect production systems

2.4 Impact assessment 
2.4.1 Recommendations - -life cycle impact assessment

3. Conclusion

Acknowledgments

References

\section{Introduction}

Insects for human food consumption and animal feed are attracting increasing attention for their potential ability to address some of the most poignant issues threatening our environment. The main reason for this is the high feed conversion efficiency of insects and their ability to feed on various feed sources (van Huis et al. 2013; Halloran et al. 2014). Therefore, at first glance, insects appear almost as a proverbial "silver bullet", providing an environmentally sustainable alternative for greening the supply of animal-source protein. However, a closer look at possible insect production systems reveals several complications and knowledge gaps that need to be addressed before the environmental benefits associated with species of edible insects in use can be assessed more precisely and their respective production systems can be utilized.

Research about insects as both food and animal feed has developed rapidly over the past decade. A growing number of scholars from a variety of scientific fields such as entomology, livestock science, protein chemistry, human nutrition, and environmental science have become interested in this new interdisciplinary area. By now, the use of edible insects is rapidly outgrowing their novelty status and they are starting to be seriously considered as food on national, regional, and local levels (Halloran et al. 2015). One notable landmark was the 2013 publication Edible insects: Future prospects for food and feed security (van Huis et al. 2013). This book, representing one of the most complete and up-to-date compilations of research into this topic, captivated a multitude of stakeholders and successfully drew significant attention to this area. Other important publications include The Food Insects Newsletter (www.foodinsectsnewsletter.org), Ecology of Food and Nutrition special issue (Paoletti and Bukkens 1997), and Ecological implications of minilivestock (Paoletti 2005). New findings are being generated every month as scaled-up production has developed in many regions of the world. In most cases, however, these companies are not yet producing at capacity (Azagoh et al. 2015).

Of particular interest in a discussion about sustainability are greenhouse gas (GHG) emissions. Eighty percent of GHG emissions generated within the agricultural sector originate from livestock production, including emissions from land used for grazing, energy for growing grains for feed, and transportation of grain and meat for processing and sale (McMichael et al. 2007). As such, alternative approaches for "greening" the protein supply abound. Insects have been identified as one of the solutions because insects' unique physiological and biological features lead to high efficiency (Fig. 1).
Compared to traditional livestock species, insects are extremely efficient at converting protein into animal protein and feed energy into food energy. This is mainly because insects are poikilothermic (cold-blooded), meaning that their metabolism is not used to maintain their body temperature, unlike homeothermic animals (Ramos-Elorduy 2008). The expected result is a higher feed conversion ratio (FCR) (also referred to in animal husbandry as feed conversion efficiency) (Nakagaki and Defoliart 1991; van Huis et al. 2013).

While insects for food and feed show great potential as an environmentally friendly choice, there is still very limited information to enable an assessment of the sustainability of the production systems to be undertaken. There are several handbooks with more specific guidelines for how to conduct LCAs (e.g. ILCD 2010) and also guidelines that are specific to food production systems (e.g., Notarnicola et al. 2015). However, just a few papers apply an environmental impact assessment method, such as life cycle assessment (LCA), to insect production systems. The LCA approach, the assumptions adopted, and the system model considered may significantly affect the results of the assessment of food production systems (Notarnicola et al. 2015).

Therefore, the main aim of this paper was to establish a versatile reference framework for choosing the best assumptions for LCA modeling of insect production systems considering both the characteristics of each system and the latest developments in food LCA. In order to achieve this aim, the objectives of the paper were (I) to describe current insect production systems highlighting critical aspects that should be considered when conducting LCA in insect production systems, (II) to review and discuss which assumptions are the most reasonable and are needed for modeling insect production systems for food and feed, and (III) to define best practices that can be adopted according to the case studies that have already published and actual critical environmental issues of insect production systems. It should be emphasized that the present paper considered studies on class Insecta (includes insects), which is the class considered by scientists in the relevant studies, and not other mainly terrestrial arthropod classes such as Arachnida (mites and spiders) and Diplopoda (including millipedes and others).

\section{Considerations for modeling insect production systems}

\subsection{LCA studies on insect production systems: general aspects}

LCA is a tool for evaluating the environmental impacts of goods and services, considering the full life cycle of the relevant product or system. In the case of food products, environmental impacts arise from the production of inputs to the 


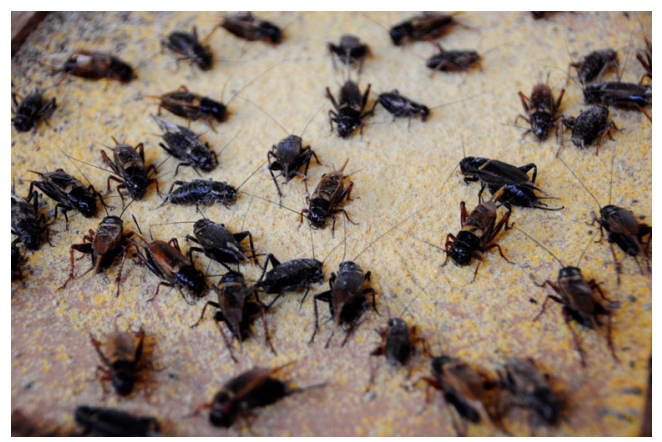

Fig. 1 Gryllus bimaculatus farmed in Khon Kaen Province, Thailand

agricultural process through to consumption in the home or restaurants and waste disposal. LCA is just one among several different environmental impact assessment methods; however, it is recognized as the most complete, it is used for the majority of food products and supply chains, and it has been adopted as the methodological base for environmental declaration schemes (Notarnicola et al. 2015).

The procedure that should be used for conducting an LCA is specified in ISO standards (ISO 14040:2006 and ISO 14044:2006). An LCA requires four main steps: (1) goal and scope definition, (2) life cycle inventory, (3) life cycle impact assessment, and (4) interpretation of results (Fig. 2). The following sections follow the same structure and discuss the aspects and considerations necessary for insect production systems for the first three steps.

\subsection{Goal and scope}

Case studies of LCA applications on edible insects for food or feed are few and far between. A search for such case studies in scientific literature yielded just six papers. The main features of the papers are preliminarily described in Table 1 .

In the goal and scope phase of an LCA, the goal of the study has to be defined as unambiguously as possible (ISO 14040: 2006 and ISO 14044:2006). This means defining the purpose of the study and usually the product or service alternatives to be compared. In order to be comparable, the products should have the same function, which is defined and quantified in the functional unit. For insect production systems, the functional unit could be the amount of edible parts (e.g., $1 \mathrm{~kg}$ of edible fraction) or animal protein (e.g., $1 \mathrm{~kg}$ of protein).

The first study on LCA applied to insect farming for human consumption was published in 2012 (Oonincx and de Boer 2012), while the first LCAs related to insects as animal feed were published in 2015 (Roffeis et al. 2015; van Zanten et al. 2015). The various goals of the studies conducted since 2012 are given in Table 1. Despite the production of insects for food and feed in countries such as Thailand, South Africa, China,

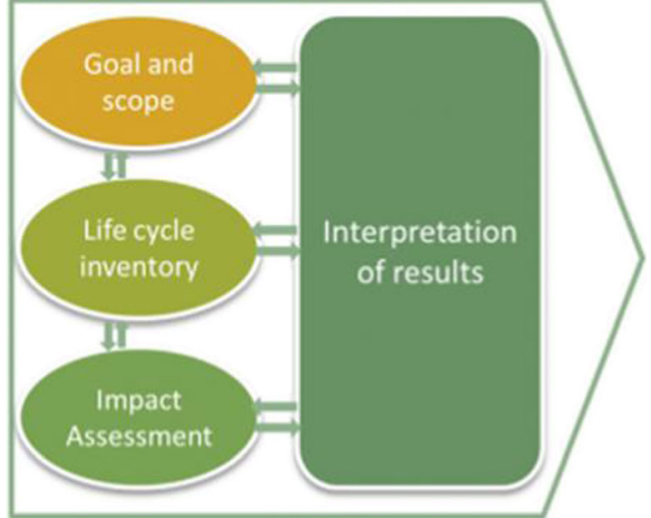

Fig. 2 Stages of a life cycle assessment (LCA) as per ISO 14044:2006

Canada, and the USA, all of the six published LCA studies focus on case studies in Europe (Table 1). Oonincx et al. (2012) collected data from a commercial mealworm (Tenebrio molitor) producer in the Netherlands, and Smetana et al. (2016) collected data from an industrial-scale black soldier fly (Hermetia illucens) producer in Germany (although foreground data was also collected from production trials). Four studies used data from experimental trials or studies (Roffeis et al. 2015; van Zanten et al. 2015; Salomone et al. 2016; Smetana et al. 2016). Smetana et al. (2015) used data from Oonincx and de Boer (2012) in their comparative study of meat alternatives and chicken. Despite the current Eurocentric research focus, growing interest and research funds (van Huis et al. 2013; Azagoh et al. 2015; Kelemu et al. 2015) dedicated to this subject should generate future LCA studies in the coming years featuring insect species used for commercially produced food and feed.

Of the known literature on the topic of insects as food and feed, each study had different objectives or goals, but of these papers, only one (Roffeis et al. 2015) had more than one objective. Three of the papers focused on the management of waste products (i.e., manure or food waste) (Roffeis et al. 2015; van Zanten et al. 2015; Salomone et al. 2016), while two papers aimed to understand the environmental impacts of insects when compared to other conventional livestock (Oonincx and de Boer 2012; Smetana et al. 2015). Smetana et al. (2016) focused on Hermita illucens for both feed and food production. Thus, there is considerable variety in the goals of the studies that have been conducted so far.

Another important aspect, therefore, is the obvious yet seldom asked question: What does the edible insect product in question intend to substitute or compete with? In many cases, the motivation to produce insects is to provide an alternative source of animal protein. However, this may not necessarily mean that less meat overall is consumed. Most commercially produced insects, such as those in Thailand or western countries, are used as snacks or novelty products (Fellows 2014; 
Table 1 A list of all papers from journals that present applications of life cycle assessment (LCA) in insects for food and feed production systems up to July 2016

\begin{tabular}{|c|c|c|c|c|c|c|}
\hline $\begin{array}{l}\text { Insect species } \\
\text { and order }\end{array}$ & Country & Goal & Functional unit(s) & Foreground data source & Assessment method & Reference \\
\hline $\begin{array}{l}\text { Tenebrio } \\
\quad \text { molitor } \\
\text { and } \\
\text { Zophobas } \\
\text { morio } \\
\text { (Coleoptera) }\end{array}$ & Netherlands & 1 & $\begin{array}{l}\text { Mass based ( } \mathrm{kg} \text { of fresh product } \\
\text { and } \mathrm{kg} \text { of edible protein) }\end{array}$ & $\begin{array}{l}\text { Commercial insect } \\
\text { producer }\end{array}$ & $\begin{array}{l}\text { Ecoinvent 1.1; IPCC } \\
2007 \text { (GWP); } \\
\text { characterization } \\
\text { factors from the } \\
\text { literature }\end{array}$ & $\begin{array}{l}\text { (Oonincx and } \\
\text { de Boer } \\
\text { 2012) }\end{array}$ \\
\hline $\begin{array}{l}\text { Musca } \\
\quad \text { domestica } \\
\quad \text { (Diptera) }\end{array}$ & Netherlands & 2 & $\begin{array}{l}\text { Mass based (ton of larvae meal } \\
\text { on dry matter basis) }\end{array}$ & Experimental studies & $\begin{array}{l}\text { Characterization } \\
\text { factors } \\
\text { from the literature; } \\
\text { IPCC } 2006 \\
\text { (GHG); Ecoinvent } \\
2.0\end{array}$ & $\begin{array}{l}\text { (van Zanten } \\
\quad \text { et al. 2015) }\end{array}$ \\
\hline $\begin{array}{l}\text { Musca } \\
\text { domestica } \\
\text { (Diptera) }\end{array}$ & $\begin{array}{l}\text { Slovakia, } \\
\text { Spain }\end{array}$ & 3,4 & $\begin{array}{l}\text { Mass based ( } \mathrm{kg} \text { of manure } \\
\text { dry matter) }\end{array}$ & Experimental trials & $\mathrm{ReCiPe}$ & $\begin{array}{l}\text { (Roffeis et al. } \\
\text { 2015) }\end{array}$ \\
\hline $\begin{array}{l}\text { Tenebrio } \\
\quad \text { molitor } \\
\text { and } \\
\text { Zophobas } \\
\text { morio } \\
\text { (Coleoptera) }\end{array}$ & Netherlands & 5 & $\begin{array}{l}\text { Mass based (kg of product ready } \\
\text { for consumptionafter assembly, } \\
\text { processing, delivering, and frying by } \\
\text { consumer); calorific energy content; } \\
\text { digestible bulk } \\
\text { protein }\end{array}$ & Literature & $\begin{array}{l}\text { ReCiPe V1.08; } \\
\text { IMPACT 2002+ }\end{array}$ & $\begin{array}{l}\text { (Smetana } \\
\quad \text { et al. 2015) }\end{array}$ \\
\hline $\begin{array}{l}\text { Hermetia } \\
\quad \text { illucens } \\
\quad \text { (Diptera) }\end{array}$ & Italy & 6 & $\begin{array}{l}\text { Mass based (ton of food waste } \\
\text { treated through larvae biodigestion, } \\
\mathrm{kg} \text { of protein and } \mathrm{kg} \text { of lipids) }\end{array}$ & Pilot plant & $\begin{array}{l}\text { CML } 2 \text { baseline } \\
\text { 2000; IPCC } 2007 \\
\text { (GWP) }\end{array}$ & $\begin{array}{l}\text { (Salomone } \\
\quad \text { et al. 2016) }\end{array}$ \\
\hline $\begin{array}{l}\text { Hermetia } \\
\quad \text { illucens } \\
\quad \text { (Diptera) }\end{array}$ & Germany & 7 & $\begin{array}{l}\text { Mass based ( } \mathrm{kg} \text { of dried defatted } \\
\text { insect powder and } \mathrm{kg} \text { of } \\
\text { ready-for-consumption fresh product at } \\
\text { processing gate) }\end{array}$ & $\begin{array}{l}\text { Industrial-scale insect } \\
\text { producer, production } \\
\text { trials }\end{array}$ & $\begin{array}{l}\text { IMPACT 2002+; } \\
\text { Eco-indicator 99; } \\
\text { CML; } \\
\text { IPCC 2007; } \\
\text { ReCiPe V1.08 }\end{array}$ & $\begin{array}{l}\text { (Smetana } \\
\quad \text { et al. 2016) }\end{array}$ \\
\hline
\end{tabular}

Country category considers the area in which the insect production takes place. Goals: 1 to compare the environmental impact of producing a given insect species with conventional sources of animal protein, 2 to assess the environmental impact of conventional livestock production when fed insects reared on waste products, 3 to estimate the sustainability and utility of insect-rearing techniques, 4 to assess substrate suitability, 5 to compare different meat substitutes with chicken, 6 to assess the environmental impacts of insect-based feed products fed with different waste products, and 7 to assess the environmental impacts of insect production for both food and feed on an industrial scale. As seen in the table above, each study addressed just one or two of these goals

Halloran et al. 2016) and therefore do not substitute animal-source foods.

The definition of the functional unit is crucial in food LCA. Several studies have shown that the impact of the results may change significantly according to the functional unit adopted in the study (Cerutti et al. 2013). All of the studies above used massbased functional units (Table 1). However, not all of the functional units pertained to an insect-based product intended for animal or human consumption. In line with their respective objectives, Roffeis et al. (2015) considered the mass of $1 \mathrm{~kg}$ of manure dry matter as their functional unit. This infers that the insect product system is considered as a waste treatment system and the insects produced are considered by-products within this study. Van Zanten et al. (2015) considered the dry weight of fly larvae, while Oonincx and de Boer (2012) and Smetana et al. (2015) considered the fresh weight of mealworms as their functional unit. Smetana et al. (2015) also employed two alternative functional units: calorific energy content and digestible bulk protein.
Smetana et al. (2016) considered dried defatted insect powder and fresh product at processing gate as the functional units. Finally, Salomone et al. (2016) considered the amount of treated waste as the functional unit. It is evident that the functional unit closely reflects the purpose of the production system, for example if it is a waste treatment system or a production system.

Cradle-to-plate (consumer use) was applied as a system boundary in two of the studies (Smetana et al. 2015; Salomone et al. 2016), while the remaining four studies used the cradle-to-farm gate system boundary (Oonincx and de Boer 2012; Roffeis et al. 2015; van Zanten et al. 2015; Smetana et al. 2016). None of the studies considered a recycling process within system boundaries. Relatively limited system boundaries were used due to a lack of data (Roffeis et al. 2015).

Only three different insect species have been the subject of LCAs on insects as food or feed (Table 1). According to the European Food Safety Agency, approximately 16 very 
different types of insect species from the orders Coleoptera, Diptera, Hemiptera, and Lepidoptera are currently farmed on a commercial basis both inside and outside Europe (EFSA Scientific Committee 2015).

\subsubsection{Recommendations — choice of functional unit}

Owing to the diversity of the scopes of the studies, it is not possible to define a specific functional unit to be applied. Clearly, it depends case by case on what the insects are being compared to. Nevertheless, it is important that the chosen functional unit is linked to one or more of the characteristics held in common between insect-based foods and competing product(s). For example, if the study focuses on the substitution of animal protein from livestock with other sources, a simple mass-based functional unit should not be used. Instead, a nutrient-based unit, such as the protein content fraction that is available to humans (or animal), should be used. Other variations of mass-based functional units that have also been used for other livestock products include per kilogram or tonne of product or per kilogram of carcass weight (de Vries and de Boer 2010; de Vries et al. 2015). On the other hand, products based on livestock proteins, vegetable protein, or edible insects may have very different prices; therefore, one way to take this into consideration is to apply an economicbased functional unit (van der Werf and Salou 2015), such as one dollar of flour used for final product preparation. When conducting studies related to insect production as a means of addressing direct malnutrition, it is relevant to employ a functional unit that considers the amount of protein or micronutrients in the product. As a general recommendation, it is suggested that different functional units be used together, in particular at least two of the three functional units, i.e., mass, nutrient, or economic-based.

\subsection{Inventory analysis}

In the inventory phase of an LCA, a system model is constructed that models the emissions and resource consumption in each of the stages of the life cycle of the analyzed product (ISO 14040: 2006 and ISO 14044:2006). In the subsections below the different stages of insect production systems are presented and the aspects that should be considered in insect production systems are discussed.

\subsubsection{Construction of facilities}

According to Sainz (2003), "intensification of animal production systems has required external inputs to achieve the high yields expected from the investment in facilities, equipment and breeding stock". Of the six LCA studies conducted on insect production (Table 1), only one considered the materials used in the constructions of buildings (Roffeis et al. 2015).
However, a sensitivity analysis found that the construction of production facilities did not substantially influence the results.

Requirements for housing and other facilities, as well as the scale and intensity of the production, vary dramatically between regions. Small-scale production found in warmer climates may be protected by simple structures. For example, the majority of Acheta domesticus and Gryllus bimaculatus production systems in Thailand are created from pens made of AAC concrete, with open sides and tin roofs, and represent a potentially low impact system (Halloran 2014). On the other hand, more advanced systems - such as those found in the Netherlands or Canada - could resemble modern facilities similar to those for domesticated livestock. Therefore, materials used for construction are often much more dependent on local conditions (i.e., climate and availability of materials) than on the type of farmed animal in question.

Here, an important question remains: are there any advantages concerning the housing or construction of other facilities for insect production when compared to other types of animal protein production? Modern industrial chicken production, for instance, is highly optimized with temperature-controlled facilities. Such units are contained within walls and have some degree of insulation. In comparison with existing A. domesticus and G. bimaculatus production systems in Thailand, this is expensive and associated with larger impacts. While the future development of insect production systems is difficult to predict, one determining factor may be whether or not it is economically advantageous to control the temperature so that insects can be produced continuously all year round. In the case of small-scale insect farming, up-scaled production will need to be treated on a case-by-case basis.

\subsubsection{Feed}

As seen from the livestock sector, the environmental impacts associated with feed production contribute a major part of total environmental impacts. Approximately $33 \%$ (470 million hectares) of the total global arable land is dedicated to animal feed production (Steinfeld et al. 2006).

The increased conversion efficiency of insects compared with other kinds of livestock holds the potential for decreasing the impacts associated with feed production. However, feed production is still likely to be responsible for a large part of the impacts. Vollrath et al. (2013) conclude that $49 \%$ of the energy used in silk production is attributed to the manufacture of fertilizers and energy for the irrigation of mulberry trees, whose leaves are consumed by the monophagous Bombyx mori. In another LCA, the main environmental impacts of Tenebrio molitor production-including global warming potential and energy and land use - are associated with mixedgrain feed in all cases (Oonincx and de Boer 2012).

The latter issue may be addressed by finding alternative feed sources. For example, Lundy and Parrella (2015) note that "identifying regionally scalable waste substrates of 
sufficient quality to produce crickets that have no direct competition from existing protein production systems might be the most promising path for producing crickets economically, with minimal ecological impact, and at a scale of relevance to the global food supply." Overall, their study concludes that the feed that the crickets are fed and the livestock systems to which they are compared will ultimately determine the environmental sustainability of crickets as a human food supply.

There may be cases where the high metabolism of insects would allow them to feed on waste or other products that could not be used for livestock. Efforts are being made to develop such systems that are efficient and not hampered by problems which may threaten hygiene and consequentially food safety (van Huis et al. 2013). Waste can be spent grains or other by-products from the food industry. However, Shockley and Dossey (2014) argue that while organic biomass such as agricultural and food by-products or low-value or novalue biomass can be used, this does not always mean that it is the option that has the lowest potential environmental impact. As such, Garnett et al. (2015) note that the by-product is a societal construct and cultural, economic, technological, and other practical factors play an important role in the consideration of what is called a by-product.

While the poikilothermic nature of insect species improves their ability to efficiently convert food into body mass, this alone cannot be the sole characteristic by which to denote edible insects as an environmentally sustainable food option. As such, scaled-up global production will ultimately mean that livestock (and even humans) and some insect species such as crickets will require and compete for the same resources. This fundamental issue, shared across other forms of livestock production, has led to the exploration of organic side streams or waste streams. Whether or not some edible insect species intended for human consumption will be permitted to be reared on such streams will ultimately be a matter of regional or national food safety regulations (EFSA Scientific Committee 2015). Lundy and Parrella (2015, p.2-3) note that "determining the feed and protein conversion efficiencies of scalable, organic side-streams is a necessary step to determining the potential for crickets to be used as a protein recovery/ recycling pathway..." Furthermore, they also note that crickets fed a similar diet to other conventional livestock will ultimately be added to the competition for feed under the trend of increasing global feed prices. It should also be considered that not all insects require a similar diet to conventional livestock. The class Insecta comprises at least one million described species and potentially several million undescribed species (Grimaldi and Engel 2005). Their natural diets differ significantly: there are foliage feeders such as crickets and many lepidopteran larvae, and there are species that naturally feed on wood or roots (Ayayee et al. 2015). Yet, other species such as aphids and mosquitoes pierce and suck from plants or animals. Predators and detrivorous species are also to be found among insects. In other words, whether or not produced insects can be compared with conventional livestock with respect to feeding must be a case-by-case evaluation.

In production systems where productivity and high turnover are core functions, insects also require feed that is formulated for rapid growth. As such, some farmed insect species may be fed high-quality, high-protein feeds (e.g., chicken feed) in order to decrease the time required to harvest. In Thailand, for example, chicken feed is preferred by farmers because its high protein content (14-21\%) enables faster growth. In their study, Nakagaki and DeFoliart (1991) fed their crickets on chicken, cricket and rabbit feed with a protein content of $22.3,17$, and $14 \%$, respectively.

Feed optimization in the livestock sector has been an important aspect of economic efficiency. Highly formulated feeds have been designed to provide animals with the right nutrition to grow quicker and larger. There is little doubt that further demand for edible insect species will generate the interest of feed producers to formulate similar feeds for insects. This has already been observed in Thailand (Halloran et al. 2016).

Less feed per body mass gained equates to less water required to water crops (van Huis et al. 2013). However, only one study focusing specifically on the water footprint of edible insect species has been carried out. In a cradle-to-farm gate approach, Miglietta et al. (2015) ${ }^{1}$ conclude that commercially produced T. molitor and Z. morio intended for human consumption have a lower water footprint $\left(0.003 \mathrm{~m}^{3} /\right.$ year/mealworm) than other traditionally farmed animals, including cattle, pigs, and broilers $\left(631,521\right.$, and $26 \mathrm{~m}^{3} /$ year/animal, respectively). However, they found that the water footprint of these species was largest when considering feed production. Therefore, three additional aspects must also be considered when evaluating the virtual water footprint associated with edible insect production: (1) how much they consume, (2) feed composition, and (3) the origin of the feed itself (Miglietta et al. 2015).

\subsubsection{Production}

Temperature Some studies have addressed the effect of temperature on the growth of crickets. According to Hoffmann (1973), the preferred temperature range for larvae of G. bimaculatus is between 34 and $36^{\circ} \mathrm{C}$. This temperature range may be considered as optimal in terms of developmental speed; however, when physiological parameters such as weight gain and mortality are taken into consideration, 34 $36^{\circ} \mathrm{C}$ is not at all optimal.

Insects have a fluctuating metabolism reflecting fluctuating temperature. According to Ayieko et al. (2015), production times for A. domesticus are highly dependent on temperature.

\footnotetext{
${ }^{1}$ This study was based on Oonincx and de Boer (2012).
} 
A. domesticus that grow at an optimal temperature of $30{ }^{\circ} \mathrm{C}$ can finish a cycle in approximately 8 weeks, while A. domesticus that grow at $18{ }^{\circ} \mathrm{C}$ can take up to 8 months to develop. Longer life cycles may possibly equate to a greater demand for inputs such as water and feed.

Energy consumption Insects are poikilothermic; therefore, their core temperature varies with environmental conditions, and thus, they have a limited ability to metabolically maintain core temperature when compared to birds and mammals (NRC 2011). As such, Clifford and Woodring (1990) recommend the use of incubators, temperature cabinets, or rooms with heat blowers to keep the ambient temperature above $25{ }^{\circ} \mathrm{C}$ when rearing A. domesticus; temperatures below $25^{\circ} \mathrm{C}$ have been found to be detrimental to growth and even threatening to survival.

Metabolic heat generation should also be considered: Larger larvae in mealworm production systems in the Netherlands were found to produce a surplus of metabolic heat and suggesting that this heat could be used to generate heat for smaller, more heat-demanding larvae (Oonincx and de Boer 2012).

At this point, insect-rearing systems have not been mechanically optimized and depend greatly on manual labor (Rumpold and Schlüter 2013). Technically sophisticated systems will, in turn, require higher energy inputs for mechanical operation and temperature control. Thus, larger, climatecontrolled facilities also bare their own environmental burdens, often through the use of fossil fuels. Oonincx et al. (2012) found high energy use on a T. molitor farm in the Netherlands. While this may certainly be the case in Europe and North America, tropical climates are better suited to providing relatively high temperatures for rearing insect species such as A. domesticus. Therefore, geographical location plays a particular role in influencing the amount of energy required to regulate temperature. According to Oonincx et al. (2012), low ambient temperatures will require higher energy inputs in insect production. In an LCA comparing mealworm, pork, milk, beef, and chicken production, mealworm production required more energy than chicken and milk production. Therefore, energy use may contribute significantly to total GHG emissions and energy use from a given production system.

Feed conversion ratio Feed conversion ratio is a common method to evaluate efficiency in livestock production. According to Nakagaki and DeFoliart (1991), "food conversion efficiency of animals is one of the important factors that must be considered in choosing environmentally sound food alternatives for the future." Other scholars have also indicated that this efficiency is an important asset in the production of commercial livestock production (Ramos-Elorduy 2008; Oonincx and de Boer 2012; van Huis et al. 2013; Oonincx et al. 2015). Feed conversion efficiency, also known as feed conversion ratio (FCR), is calculated as follows:

$\frac{\text { Mass of the feed consumed }}{\text { Fresh weight of edible component }}=$ FCR

FCR is not a fixed number. Table 2 demonstrates that FCR is difficult to compare between studies. Most studies have been conducted in laboratory settings and may not accurately represent variations between farms. Moreover, previous studies conducted on feed-to-protein conversion by edible insect species (Nakagaki and Defoliart 1991; Collavo et al. 2005; Offenberg 2011) have been conducted on low population densities which are not economically viable (Lundy and Parrella 2015) or with different diets and densities. Thus, the context under which the system is analyzed will define the relative environmental benefits of cultivating insect species. For example, in their study of biomass output and feed conversion ratios, Lundy and Parrella (2015) note that commercially produced $A$. domesticus fed grain-based diets exhibit improved feed conversion efficiency when compared to livestock species. They also found that higher-density A. domesticus populations have higher or less efficient FCRs.

In another explanation of the differences in FCRs for insects, Oonincx et al. (2015) note that protein density and composition are the most important determinants of growth rates and efficiencies. This is because insects do not use energy to maintain body temperature. On the other hand, the energy content of feed plays a much more important role in the growth rates and efficiency of conventional livestock.

FCR is also linked to temperature (see 2.2.1.3). For example, Nakagaki and DeFoliart (1991) found that crickets have a lower reported FCR than broiler chicks and pigs at a temperature of $30{ }^{\circ} \mathrm{C}$ or higher. At the same temperature, crickets have an even lower FCR when compared to sheep and cattle.

Another example of the differences in FCR is that of B. mori. Ingesting the same amount of mulberry leaves under different environmental, feeding, and nutritional conditions affects its ability to digest, absorb, and convert the ingested leaves to body matter (Rahmathulla and Suresh 2012). Additional factors influencing FCR include the dressing percentage (the body of an animal after the hide, head, tail, extremities, and viscera have been removed) and the carcass refuse. The edible fraction of an insect is generally much higher than that of vertebrate livestock (Nakagaki and Defoliart 1991). In contrast, often the entire insect (except appendages and wings for adults) is eaten. Current vocabulary for comparing edible parts with vertebrate "meat" and other parts such as "liver" is simply missing (Evans et al. 2015), which hampers comparisons of the efficacy of insects versus vertebrates.

However, using FCR to evaluate the environmental impacts of some insect species compared to livestock 
Table 2 Select examples of feed conversion ratio (FCR) in the production of edible insects for human consumption

\begin{tabular}{|c|c|c|c|c|c|}
\hline Species & FCR & Feed & $\begin{array}{l}\text { Metamorphic } \\
\text { state }\end{array}$ & Average temperature & Source \\
\hline \multirow[t]{3}{*}{$\begin{array}{l}\text { Tenebrio } \\
\quad \text { molitor }\end{array}$} & 2.2 & $\begin{array}{l}\text { Mixed grains (wheat bran, oats, soy, } \\
\text { rye, and corn supplemented with } \\
\text { beer yeast) and carrots }\end{array}$ & Adult & $\begin{array}{l}\text { Unknown (a temperature-controlled } \\
\text { environment) }\end{array}$ & $\begin{array}{l}\text { (Oonincx and de Boer } \\
\text { 2012) }\end{array}$ \\
\hline & $3.8 \pm 0.63$ & $\begin{array}{l}\text { High protein, high fat diet ( } 60 \% \\
\text { spent grains, } 20 \% \text { beer yeast, } \\
20 \% \text { cookie remains) }\end{array}$ & 116 days \pm 5.2 & $28{ }^{\circ} \mathrm{C}$ & (Oonincx et al. 2015) \\
\hline & $5.3 \pm 0.81$ & $\begin{array}{l}\text { Low-protein, high-fat diet (50\% } \\
\text { cookie remains and } 50 \% \text { bread) }\end{array}$ & $191 \pm 21.9$ & $28{ }^{\circ} \mathrm{C}$ & (Oonincx et al. 2015) \\
\hline \multirow[t]{6}{*}{$\begin{array}{l}\text { Acheta } \\
\quad \text { domesticus }\end{array}$} & 1.47 & $\begin{array}{l}\text { Poultry feed (primarily of maize and } \\
\text { soy grain products) }\end{array}$ & 33 days & $29.0 \pm 2.1 \mathrm{SD}^{\circ} \mathrm{C}$ & $\begin{array}{l}\text { (Lundy and Parrella } \\
\text { 2015) }\end{array}$ \\
\hline & 1.91 & $\begin{array}{l}\text { Grocery store food waste enzymatically } \\
\text { converted into } 90 \% \text { liquid fertilizer } \\
\text { and } 10 \% \text { solids }\end{array}$ & 44 days & $29.0 \pm 2.1 \mathrm{SD}^{\circ} \mathrm{C}$ & $\begin{array}{l}\text { (Lundy and Parrella } \\
\text { 2015) }\end{array}$ \\
\hline & 1.65 & Purina Rabbit Chow & Eighth instar & $33-35 \pm \mathrm{SD}{ }^{\circ} \mathrm{C}$ & $\begin{array}{l}\text { (Nakagaki and } \\
\text { Defoliart 1991) }\end{array}$ \\
\hline & 1.08 & $\begin{array}{l}\text { Selph's cricket feed (ingredients not } \\
\text { disclosed) }\end{array}$ & Eighth instar & $33-35 \pm \mathrm{SD}{ }^{\circ} \mathrm{C}$ & $\begin{array}{l}\text { (Nakagaki and } \\
\text { Defoliart 1991) }\end{array}$ \\
\hline & 1.69 & $\begin{array}{l}\text { Human refuse diet (fruits and } \\
\text { vegetables } 34 \% \text {, rice and } \\
\text { pasta } 27 \% \text {, pork and beef } \\
\text { meat } 11 \% \text {, bread } 11 \% \text {, cheese } \\
\text { skins } 11 \% \text {, yolk } 6 \% \text { ) }\end{array}$ & 45 days & $30.5^{\circ} \mathrm{C}$ & (Collavo et al. 2005) \\
\hline & $4.5 \pm 2.84$ & $\begin{array}{l}\text { High protein, high fat ( } 60 \% \text { spent grains, } \\
20 \% \text { beer yeast, } 20 \% \text { cookie remains) }\end{array}$ & $55 \pm 7.3$ & $28^{\circ} \mathrm{C}$ & (Oonincx et al. 2015) \\
\hline
\end{tabular}

species is questionable. The reason for this has to do with the fact that FCR considers fresh weight. This means that a high FCR can be achieved if the final product has a high water content. FCR does not consider the digestibility of the product. For example, for insect species where the exoskeleton is eaten, a low FCR is achieved; however, the exoskeleton is not digestible and does not provide nutritional value. However, it should be noted that chitinases (enzymes which breakdown chitin) have been found in the intestines of human populations with a higher rate of entomophagy (Paoletti et al. 2007).

As Garnett et al. (2015) ask: "But what is efficiency? What are we being efficient with and efficient for?" Rather than being a scientific means for calculating efficiency and environmentally sustainable optimization of feed resources, FCR appears to be a unit employed to calculate economic efficiency rather than resource efficiency.

Water The high feed conversion rates of insects, therefore, correspond to their water use efficiency (Oonincx and de Boer 2012; Shockley and Dossey 2014). However, there has been limited research on the topic of water consumption by production insects.
Greenhouse gas emissions GHG emissions play an important role in the impacts generated during livestock production, and one of the potential benefits of instigating insect production systems may be the reduction of these emissions. It is well known that some insects produce large amounts of methane. However, in general, very little information is available about emissions of greenhouse gases from insects used in production systems. In 2010, Oonincx et al. conducted a study of the greenhouse gas and ammonium emissions associated with T. molitor, A. domesticus, and Locusta migratoria. They note that $\mathrm{CO}_{2}$ production is highly dependent on species, metamorphic stage, temperature, feeding status, and level of activity. A follow-up LCA study on $T$. molitor production demonstrates that the land use and GHG emissions are less than for pigs, chickens, and cattle per kilogram of animal protein (Oonincx and de Boer 2012).

Termites are consumed in many countries, most commonly in sub-Saharan Africa (van Huis et al. 2013). While termites are reportedly very difficult to farm intensively (Kinyuru et al. 2015), methanogenic bacteria that inhabit their guts can generate a significant amount of methane (between $<5$ and $19 \%$ of global $\mathrm{CH}_{4}$ emissions) (Jamali et al. 2011). Methanogenic bacteria have also been found to occur in the hindguts of nearly all tropical representatives of cockroaches (Blattaria), termites (Isoptera), and scarab beetles (Scarabaeidae) (Hackstein and Stumm 1994). However, environmental 
conditions, such as light, humidity, temperature, and $\mathrm{CO} 2$ and $\mathrm{O} 2$ concentrations, have been found to play a role in determining the amount of methane that is produced (Velu et al. 2011). Therefore, there is potential for optimizing the systems not only for the highest efficiency in terms of production but also to lower GHG emissions.

Additional inputs In other industrial farming operations, some additional inputs include antibiotics, vitamins, and vaccines. These affect freshwater ecosystems and increase the probability of the development of resistant pathogens that can be transferred to humans. The use of antibiotics in the industry is most likely very low. Whether or not the use of antibiotics or vitamins will be seen on insect farms will be determined by the future development of the industry. It is not unlikely, however, as they are used in very diverse production systems including shrimp (also an arthropod group) farms (Holmstrom et al. 2003).

\subsubsection{Transport}

Whether insects will require more or less energy and resources for transportation compared with other livestock products is difficult to answer. Currently, production is much more localized than livestock production, which is a global industry with large transport distances. However, of the commercially produced insects in Europe, some companies produce freezedried products.

In the agri-food industry, transportation stages are often reported to be one of the most significant impact categories (Roy et al. 2009). Freeze drying could potentially lower the environmental impacts associated with transport by lowering the density of the insect product.

\subsubsection{Processing and storage}

The perishability of livestock products ranks high compared with other food products. Thus, chilling and processing are significant processes that are needed to mitigate any negative effects on quality and human health (Steinfeld et al. 2006). When considering the environmental impacts associated with processing and storing livestock, it may be relevant to take these steps in the production chain into account. In fact, $\mathrm{CO}_{2}$ emissions from livestock processing total several tens of million tonnes per year (Steinfeld et al. 2006). If processing and storage techniques for insects are similar to those for livestock, this process may contribute significantly to the environmental impacts associated with edible insect production. On the other hand, it may also be possible to devise alternative storage methods for insects, including preservation using salt and freeze drying. However, these may not always be the desired means of storing these products and freeze drying may lead to higher energy use.
Freeze-dried insects have also been found for sale mainly in Europe and North America. Freeze drying is recognized as the most expensive dehydration technique (Ratti 2001) and is reported to consume significant amounts of energy (Huang et al. 2009).

In some countries, B. mori pupae (found inside the cocoon and also known as chrysalis) are consumed as edible coproducts of silk production (FAO 2010). In a preliminary study, Vollrath et al. (2013) found that cooking the cocoons to extract the silk is responsible for $51 \%$ of the primary energy consumption. In this sector, Vollrath et al. (2013) consider economies of scale to be an important factor in reducing total energy consumption. However, this may not be desirable, or even possible, for all farmers.

In a study analyzing microbiological hygiene parameters during storage, fresh and heat-treated crickets were placed in the refrigerator at $4-6{ }^{\circ} \mathrm{C}$ and at room temperature $\left(28-30{ }^{\circ} \mathrm{C}\right.$ in Lao PDR) (Klunder et al. 2012). The boiled A. domesticus were found to spoil quickly, whereas the refrigerated crickets could be stored for up to 2 weeks. Whole insects, like other animal-source products, contain gut microflora that provide a medium for the growth of unwanted microorganisms under certain conditions (Klunder et al. 2012). Therefore, refrigeration is an important aspect for consideration in future cradleto-market analysis.

However, little else is known about the impacts of processing other kinds of insects. Oonincx et al. (2012) note that there are no standardized processing and storing methods for T. molitor, making it difficult to generalize. In reviewing numerous studies conducted to quantify the energy costs of processing animals for meat and other products, Sainz (2003) also notes that it is very difficult to make a general assumption.

\subsubsection{Waste management and nutrient recycling}

Management of animal waste in livestock production is known to be associated with large environmental impacts, including emissions of greenhouse gases such as methane and nitrous oxide, ammonia volatilization, and leaching of nitrate (Steinfeld et al. 2006).

There is no available information about emissions from storage facilities or after land application of waste produced in insect production systems. The management of waste from insect production is likely to be associated with the same impacts. One way in which it may differ from the situation in many livestock production systems is the fact that the waste is often quite dry. This means that emissions of nitrous oxide and methane during storage may be lower than from many waste types from livestock production systems. However, it may also mean that ammonia is volatilized relatively quickly already during rearing or storage.

In agroecosystems, insect frass plays an important role. Kagata and Ohgushi (2012) found that the decomposition of 
frass in the soil is an important pathway by which herbivorous insects impact decomposition and soil nutrient availability. In Thailand, A. domesticus and G. bimaculatus farmers report that the frass is beneficial to their rice fields (Halloran 2014, unpublished data). Another study in the USA suggested that $H$. illucens larvae solid residues from food scrap processing applied to corn plants (Zea mays) stunted plant growth (Alattar et al. 2016). Several companies in the Netherlands, China, and the USA are already selling fertilizers made from H. illucens or T. molitor frass.

\subsubsection{Recommendations - modeling of the insect production systems}

The first important step is to define whether insects are grown for human consumption or as a waste treatment process and to construct the model in accordance with the system. In the event that some insects have both functions, a coherent LCA study of such systems should consider, through the application of an industrial ecology approach, other production systems that use outputs from other systems as inputs (e.g., Chiusano et al. 2015). In an LCA setting, this means that by-products will need to be handled by either allocation or system expansion for a combined functional unit, entailing the definition of both waste treatment and insect production.

The modeling of waste management and nutrient cycling in scaled-up scenarios is crucial because little is understood about the introduction of large amounts of insect frass (i.e., manure) to agricultural systems and the impact this may have on ecosystems.

Scaled-up scenarios that model large-scale production reflecting future scenarios or more realistic conditions than the ones under small-scale production in Europe are also recommended. An increase in case studies featuring production systems outside Europe is strongly recommended in order to understand the differences between geographical location, preferred species, and other local factors.

When calculating resource efficiency, digestible dry matter, crude protein, or other factors should be considered. Above all, future studies should aim to include more unit processes such as processing and storage as well as waste management and nutrient cycling.

\subsection{Impact assessment}

The use of different environmental impact assessment methods may lead to different conclusions across LCAs (Notarnicola et al. 2015). Of the 22 different impact categories used in the six studies first introduced in Table 1, climate change (expressed in GWP) is measured in three of the studies (Table 3). However, it should be noted that not all of the studies address the same impact categories.
The most important impact categories to consider are probably the ones relevant for other livestock production systems, such as climate change, eutrophication, land use, and, in many situations, water consumption and fossil fuel depletion.

Mealworm production requires $43 \%$ of the amount of land used for milk and $10 \%$ of the land required for beef production (Oonincx et al. 2010).

For the studies that considered climate change as an impact category, the largest contributor to this impact category is the feed (also referred to as substratum) (Oonincx and de Boer 2012; Smetana et al. 2015; van Zanten et al. 2015; Salomone et al. 2016; Smetana et al. 2016). However, it must be noted that as feed compositions vary so do their impacts in terms of climate change. When compared to conventional livestock in an assessment of impact categories with regard to climate change, insects perform better (Oonincx and de Boer 2012; Smetana et al. 2015).

\subsubsection{Recommendations - life cycle impact assessment}

If the overall environmental sustainability of insect production is to be taken into account, then all potential impact categories must be considered. Nevertheless, the more impact categories that are considered the less straightforward their interpretation might be. The choice of which impact category to consider is an open question in LCA research and general recommendations can be found in Hauschild and Huijbregts (2015). According to the hypothesis that edible insects will mostly be compared to food production systems, it is suggested that the most used impact categories in the agricultural sector are used (Notarnicola et al. 2015), in particular climate change, resource consumption, nutrient enrichment potential, and acidification potential, together with an indicator of potential impacts on land use and water consumption, owing to the specificities of insect production systems. Furthermore, it is important to consider that as edible insects spread in the market, new environmental hotspots can emerge, forcing the inclusion of new impact categories.

More data on greenhouse gas emissions of farmed insect species are required to further understanding about the GWP of insects. This aspect would also be important for guiding the market, as the insect species that are most acceptable or preferred to farm should take the highest priority.

\section{Conclusion}

Considering the few publications available on the topic, it is clear that research on LCAs of edible insects is in its infancy and that it is difficult to draw general conclusions about the overall environmental impact of insect 
Table 3 Impact categories used in the assessment of environmental impacts associated with the five papers in this literature review

\begin{tabular}{|c|c|c|c|c|c|c|}
\hline Impact categories & $\begin{array}{l}\text { (Oonincx and de Boer } \\
2012)^{1}\end{array}$ & $\begin{array}{l}\text { (van Zanten et al. } \\
\text { 2015) }\end{array}$ & $\begin{array}{l}\text { (Roffeis et al. } \\
\text { 2015) }\end{array}$ & $\begin{array}{l}\text { (Smetana et al. } \\
\text { 2015) }\end{array}$ & $\begin{array}{l}\text { (Salomone et al. } \\
\text { 2016) }\end{array}$ & $\begin{array}{l}\text { (Smetana et al. } \\
\text { 2016) }\end{array}$ \\
\hline $\begin{array}{l}\text { Climate change (expressed } \\
\text { in GWP) }\end{array}$ & $\mathrm{X}$ & $\mathrm{X}$ & & & $\mathrm{X}$ & \\
\hline $\begin{array}{l}\text { Climate change- } \\
\text { ecosystems }\end{array}$ & & & & $\mathrm{X}$ & & $\mathrm{X}$ \\
\hline $\begin{array}{l}\text { Climate change - human } \\
\text { health }\end{array}$ & & & & $\mathrm{X}$ & & $\mathrm{X}$ \\
\hline Ozone depletion & & & & $\mathrm{X}$ & $\mathrm{X}$ & $\mathrm{X}$ \\
\hline Human toxicity & & & & $\mathrm{X}$ & $\mathrm{X}$ & $\mathrm{X}$ \\
\hline $\begin{array}{l}\text { Photochemical oxidant } \\
\text { formation }\end{array}$ & & & & $\mathrm{X}$ & $\mathrm{X}$ & $\mathrm{X}$ \\
\hline Particulate matter formation & & & & $\mathrm{X}$ & & $\mathrm{X}$ \\
\hline Ionizing radiation & & & & $\mathrm{X}$ & & $\mathrm{X}$ \\
\hline Terrestrial acidification & & & & $\mathrm{X}$ & $\mathrm{X}$ & $\mathrm{X}$ \\
\hline Freshwater eutrophication & & & & $\mathrm{X}$ & $\mathrm{X}$ & $\mathrm{X}$ \\
\hline Terrestrial ecotoxicity & & & & $\mathrm{X}$ & $\mathrm{X}$ & $\mathrm{X}$ \\
\hline Freshwater ecotoxicity & & & & $\mathrm{X}$ & $\mathrm{X}$ & $\mathrm{X}$ \\
\hline Marine ecotoxicity & & & & $\mathrm{X}$ & $\mathrm{X}$ & $\mathrm{X}$ \\
\hline Agricultural land occupation & & & $\mathrm{X}$ & $\mathrm{X}$ & & $\mathrm{X}$ \\
\hline Urban land occupation & & & & $\mathrm{X}$ & & $\mathrm{X}$ \\
\hline Natural land transformation & & & & $X$ & & $\mathrm{X}$ \\
\hline Metal depletion & & & & $X$ & & $\mathrm{X}$ \\
\hline Fossil depletion & & & $\mathrm{X}$ & $\mathrm{X}$ & & $\mathrm{X}$ \\
\hline Abiotic depletion & & & & & $\mathrm{X}$ & \\
\hline Energy use & $X$ & $\mathrm{X}$ & & & & \\
\hline Land use & $\mathrm{X}$ & $\mathrm{X}$ & & & & \\
\hline Water depletion potential & & & $\mathrm{X}$ & & & \\
\hline
\end{tabular}

${ }^{1}$ The water depletion potential (water footprint) of mealworm production was calculated by Miglietta et al. 2015 using data from Oonincx and de Boer 2012

production systems. While insects do have some unique characteristics that provide them with great potential for use in the efficient and environmentally friendly production of animal protein, further life cycle perspectives must take into account the full ramifications of insects in human diets. As a consequence, more LCAs concerning insect production are needed. These must also, where possible, include construction, feed, production, transport, processing and storage, and waste management and nutrient recycling processes. In addition, future LCAs on insect production systems must consider the following list of interrelated points:

1. Clear definition of the insect species and life stages included in the LCA

2. Use of at least two of the following types of functional units: nutritional, mass, or economic-based

3. Collection of empirical data in situ (e.g., on farms/ production sites) (a) Life cycle inventories that reflect the complexity of and realistic conditions for the production in question and future, scaled-up scenarios

(b) Empirical data on greenhouse gas and ammonia emissions from the specific insect species and developmental stage in question

4. Comparative analysis where production systems are producing products that are realistic alternatives to the insect species under investigation, or production systems located in different locations or different kinds or scale of production systems

(a) Consideration of the comparability of insects and conventional livestock or other products must be performed on a case-by-case evaluation

(b) Definition of production systems in a way that makes a comparison with other studies of livestock production systems (insects and other livestock) possible across countries and livestock species 
5. Inclusion of more unit processes outside direct production, such as processing and storage and waste management

6. Use of a wide range of impact categories, especially climate change, resource consumption, nutrient enrichment potential, acidification potential, and impacts on land and water consumption; however, it is always better to select some impact categories that can be measured with methods that can assure high-quality data, rather than providing a broad overview based on less valid data

(a) Attention should also be paid to the emergence of the importance of impact categories that have not proven significant in other LCAs of feed production systems.

Acknowledgments Thank you to the two anonymous reviewers for their useful comments. This research was supported by the Social Sciences and Humanities Research Council of Canada Doctoral Research Grants (752-2015-0271) and the Consultative Research Committee for Development Research of the Danish International Development Agency (13-06KU - GREEiNSECT), the Danish Ministry of Foreign Affairs, and the University of Copenhagen.

\section{References}

Alattar MA, Alattar FN, Ropa R (2016) Effects of microaerobic fermentation and black solider fly larvae food scrap processing residues on the growth of corn plants (Zea mays). Plant Sci Today 3:57-62. doi:10.14719/pst.2016.3.1.179

Ayayee PA, Larsen T, Rosa C, et al. (2015) Essential amino acid supplementation by gut microbes of a wood-feeding Cerambycid. Environ Entomol 45:66-73. doi:10.1093/ee/nvv153

Ayieko M., Kinyuru JN, Makhado R, et al (2015) Locusts and grasshoppers (Orthoptera). In: Edible insects in Africa: an introduction to finding, using and eating insects. CTA Publications Distribution Service, Wageningen, pp 45-54

Azagoh C, Hubert A, Mezdour S (2015) Insect biorefinery in Europe: "DESigning the insect bioRefinery to contribute to a more sustainABLE agro-food industry". J Insect Food Feed 1:159-168. doi:10.3920/JIFF2014.0009

Cerutti AK, Bruun S, Donno D, et al. (2013) Environmental sustainability of traditional foods: the case of ancient apple cultivars in Northern Italy assessed by multifunctional LCA. J Clean Prod 52:245-252. doi:10.1016/j.jclepro.2013.03.029

Chiusano L, Cerutti AK, Cravero MC, et al. (2015) An industrial ecology approach to solve wine surpluses problem: the case study of an Italian winery. J Clean Prod 91:56-63. doi:10.1016/j.jclepro.2014.12.002

Clifford CW, Woodring JP (1990) Methods for rearing the house cricket, Acheta domesticus (L.), along with baseline values for feeding rates, growth rates, development times, and blood composition. J Appl Entomol 109:1-14. doi:10.1111/j.1439-0418.1990.tb00012.x

Collavo A, Glew RH, Huang YS, et al. (2005) House cricket small-scale farming. In: Paoletti MG (ed) Ecological implications of minilivestock: potential of insects, rodents, frogs and snails. Science Publishers, Enfield, pp. 519-544

de Vries M, de Boer IJM (2010) Comparing environmental impacts for livestock products: a review of life cycle assessments. Livest Sci 128:1-11. doi:10.1016/j.livsci.2009.11.007 de Vries M, van Middelaar CE, de Boer IJM (2015) Comparing environmental impacts of beef production systems: a review of life cycle assessments. Livest Sci 178:279-288. doi:10.1016/j.livsci.2015.06.020

EFSA Scientific Committee (2015) Risk profile related to the production and consumption of insects as food and feed. EFSA J 13:1-60. doi:10.2903/j.efsa.2015.4257

Evans J, Alemu M h, Flore R, et al. (2015) "Entomophagy": an evolving terminology in need of review. J Insect Food Feed 1:293-305. doi:10.3920/JIFF2015.0074

FAO (2010) Edible forest insects: humans bite back. Food and Agriculture Organization of the United Nations Regional Office Asia and the Pacific, Bangkok

Fellows P (2014) Insect products for high-value western markets. Food Chain 4:119-128. doi:10.3362/2046-1887.2014.012

Garnett T, Röös E, Little D (2015) Lean, green, mean, obscene...? What is efficiency? And is it sustainable? Animal production and consumption reconsidered. Food Climate Research Network, Oxford

Grimaldi D, Engel M (2005) Evolution of the insects, 1st edn. Cambridge University Press, Cambridge

Hackstein JH, Stumm CK (1994) Methane production in terrestrial arthropods. Proc Natl Acad Sci U S A 91:5441-5445

Halloran, A (2014). Input and output data from Thai cricket farms in northeastern Thailand. University of Copenhagen, Copenhagen. Unpublished data, cited with permission

Halloran A, Müenke C, van Huis A, Vantomme P (2014) Insects in the human food chain: global status and opportunities. Food Chain 4: 103-118. doi:10.3362/2046-1887.2014.011

Halloran A, Vantomme P, Hanboonsong Y, Ekesi S (2015) Regulating edible insects: the challenge of addressing food security, nature conservation, and the erosion of traditional food culture. Food Sec 7: 739-746. doi:10.1007/s12571-015-0463-8

Halloran A, Roos N, Flore R, Hanboonsong Y (2016) The development of the edible cricket industry in Thailand. J Insect Food Feed in press:in press. doi:10.3920/JIFF2015.0091

Hauschild MZ, Huijbregts MAJ (eds) (2015) Life cycle impact assessment. Springer Netherlands, Dordrecht

Hoffmann K-H (1973) Der Einfluß der Temperatur auf die chemische Zusammensetzung von Grillen (Gryllus, Orthopt.). Oecologia 13: 147-175. doi:10.1007/BF00345646

Holmstrom K, Graslund S, Wahlstrom A, et al. (2003) Antibiotic use in shrimp farming and implications for environmental impacts and human health. Int J Food Sci Tech 38:255-266. doi:10.1046 j.1365-2621.2003.00671.x

Huang L, Zhang M, Mujumdar AS, Sun D, Tan G, Tang S (2009) Studies on decreasing the consumption for a freeze-drying of apple slices. Dry Technol 37:238-946. doi:10.1080/07373930902901844

ILCD (2010) International reference life cycle data system (ILCD) handbook - general guide for life cycle assessment - detailed guidance, 1 st edn. Publications Office of the European Union, Luxembourg

Jamali H, Livesley SJ, Dawes TZ, et al. (2011) Diurnal and seasonal variations in $\mathrm{CH} 4$ flux from termite mounds in tropical savannas of the northern territory, Australia. Ag Forest Meteorol 151:14711479. doi:10.1016/j.agrformet.2010.06.009

Kagata H, Ohgushi T (2012) Positive and negative impacts of insect frass quality on soil nitrogen availability and plant growth. Popul Ecol 54: 75-82. doi:10.1007/s10144-011-0281-6

Kelemu S, Niassy S, Torto B, et al. (2015) African edible insects for food and feed: inventory, diversity, commonalities and contribution to food security. J Insect Food Feed 1:103-119. doi:10.3920 /JIFF2014.0016

Kinyuru JN, Mogendi JB, Riwa CA, Ndung'u NW (2015) Edible insects - a novel source of essential nutrients for human diet: learning from traditional knowledge. Anim Front 5:14-19

Klunder HC, Wolkers-Rooijackers J, Korpela JM, Nout MJR (2012) Microbiological aspects of processing and storage of edible insects. Food Control 26:628-631. doi:10.1016/j.foodcont.2012.02.013 
Lundy ME, Parrella MP (2015) Crickets are not a free lunch: protein capture from scalable organic side-streams via high-density populations of Acheta domesticus. PLoS One 10:e118785. doi:10.1371 journal.pone. 0118785

McMichael AJ, Powles JW, Butler CD, Uauy R (2007) Food, livestock production, energy, climate change, and health. Lancet 370:12531263. doi:10.1016/S0140-6736(07)61256-2

Miglietta P, De Leo F, Ruberti M, Massari S (2015) Mealworms for food: a water footprint perspective. Water 7:6190-6203. doi:10.3390 /w7116190

Nakagaki BJ, Defoliart GR (1991) Comparison of diets for mass-rearing Acheta domesticus (Orthoptera: Gryllidae) as a novelty food, and comparison of food conversion efficiency with values reported for livestock. J Econ Enomol 84:891-896

Notarnicola B, Salomone R, Petti L, et al. (eds) (2015) Life cycle assessment in the Agri-food sector. Springer International Publishing, Switzerland

NRC (2011) Guide for the care and use of laboratory animals: committee for the update of the guide for the care and use of laboratory animals, 8th edn. National Academies Press, Washington DC

Offenberg J (2011) Oecophylla smaragdina food conversion efficiency: prospects for ant farming. Appl Entomol 135:575-581

Oonincx DGAB, de Boer IJM (2012) Environmental impact of the production of mealworms as a protein source for humans - a life cycle assessment. PLoS One 7:e51145. doi:10.1371/journal.pone.0051145

Oonincx DGAB, van Itterbeeck J, Heetkamp MJW, et al. (2010) An exploration on greenhouse gas and ammonia production by insect species suitable for animal or human consumption. PLoS One 5: e14445. doi:10.1371/journal.pone.0014445

Oonincx DGAB, van Broekhoven S, van Huis A, van Loon JJA (2015) Feed conversion, survival and development, and composition of four insect species on diets composed of food by-products. PLoS One 10:e0144601. doi:10.1371/journal.pone.0144601

Paoletti M (ed) (2005) Ecological implications of minilivestock. Scientific Publishers, Plymouth

Paoletti M, Bukkens S (eds) (1997) Minilivestock [special issue] Ecol Food Nutr. 36 (2-4). doi:10.1080/03670244.1997.9991508

Paoletti M, Norberto L, Damini R, Musumeci S (2007) Human gastric juice contains chitinase that can degrade chitin. Ann Nutr Metab 51: 244-251. doi:10.1159/000104144

Rahmathulla VK, Suresh HM (2012) Seasonal variation in food consumption, assimilation, and conversion efficiency of Indian Bivoltine hybrid silkworm, Bombyx mori. J Insect Sci 12:1-14. doi:10.1673/031.012.8201

Ramos-Elorduy J (2008) Energy supplied by edible insects from Mexico and their nutritional and ecological importance. Ecol Food Nutr 47: 280-297. doi:10.1080/03670240701805074
Ratti C (2001) Hot air and freeze-drying of high-value foods: a review. J Food Eng 49:311-319. doi:10.1016/S0260-8774(00)00228-4

Roffeis M, Muys B, Almeida J, et al. (2015) Pig manure treatment with housefly ( Musca domestica ) rearing - an environmental life cycle assessment. J Insect Food Feed 1:195-214. doi:10.3920/JIFF2014.0021

Roy P, Nei D, Orikasa T, et al. (2009) A review of life cycle assessment (LCA) on some food products. J Food Eng 90:1-10. doi:10.1016/j. jfoodeng.2008.06.016

Rumpold BA, Schlüter OK (2013) Nutritional composition and safety aspects of edible insects. Mol Nutr Food Res 57:802-823

Sainz RD (2003) Livestock-environment initiative fossil fuels component: framework for calculating fossil fuel use in livestock systems. Food and Agriculture Organisation of the United Nations, Rome

Salomone R, Saija G, Mondello G, et al. (2016) Environmental impact of food waste bioconversion by insects: application of life cycle assessment to process using Hermetia illucens. J Clean Prod, in press. doi:10.1016/j.jclepro.2016.06.154

Shockley M, Dossey AT (2014) Chapter 18 - insects for human consumption. In: Morales-Ramos J, Rojas G, Shapiro-Ilan D (eds) Mass production of beneficial organisms. Academic Press, San Diego, pp. 617-652

Smetana S, Mathys A, Knoch A, Heinz V (2015) Meat alternatives: life cycle assessment of most known meat substitutes. Int J Life Cycle Assess 20:1254-1267. doi:10.1007/s11367-015-0931-6

Smetana S, Palanisamy M, Heinz V (2016) Sustainability of insect use for feed and food: life cycle assessment perspective. J Clean Prod, in press. doi:10.1016/j.jclepro.2016.07.148

Steinfeld H, Gerber P, Wassenaar T, et al. (2006) Livestock's long shadow. Food and Agriculture Organization of the United Nations, Rome

van der Werf HMG, Salou T (2015) Economic value as a functional unit for environmental labelling of food and other consumer products. J Clean Prod 94:394-397. doi:10.1016/j.jclepro.2015.01.077

van Huis A, Van Itterbeeck J, Klunder H, et al (2013) Edible insects: future prospects for food and feed security. Food and Agriculture Organization of the United Nations

van Zanten HHE, Mollenhorst H, Oonincx DGAB, et al. (2015) From environmental nuisance to environmental opportunity: housefly larvae convert waste to livestock feed. J Clean Prod 102:362-369. doi:10.1016/j.jclepro.2015.04.106

Velu G, Ramasamy K, Kumar K, et al. (2011) Green house gas emissions from termite ecosystem. J Env Sci Tech 5:56-64

Vollrath F, Carter R, Rajesh GK, et al (2013) Life cycle analysis of cumulative energy demand on sericulture in Karnataka, India. Padua, Italy, p 12 